\title{
EVALUASI PELAKSANAAN PROGRAM ADIWIYATA DALAM MEWUJUDKAN SEKOLAH PEDULI DAN BERBUDAYA LINGKUNGAN DI SDN MODEL BANYUWANGI
}

\author{
Griselda Malinda E.P. ${ }^{1}$, Sayu Larasati Nabila ${ }^{1}$, Septa Indra Puspikawati \\ ${ }^{1}$ Departemen Kesehatan Lingkungan, Program Studi S1 Kesehatan Masyarakat PSDKU UNAIR di Banyuwangi, Jl. \\ Wijaya Kusuma No.113, Mojopanggung, Banyuwangi, Jawa Timur 68432, Indonesia \\ email: griselda.malinda.eliza-2016@fkm.unair.ac.id \\ ${ }^{2}$ Departemen Gizi Kesehatan, Program Studi S1 Kesehatan Masyarakat PSDKU UNAIR di Banyuwangi \\ Jl. Wijaya Kusuma No.113, Mojopanggung, Banyuwangi, Jawa Timur 68432, Indonesia \\ email: septaindra@fkm.unair.ac.id
}

\begin{abstract}
Abstrak
Pendidikan lingkungan hidup merupakan alternatif upaya yang dilakukan untuk menanamkan karakter peduli lingkungan pada usia dini. Jenis penelitian adalah penelitian observasional yang dilakukan pada 20 \& 22 April 2019 di SDN Model Banyuwangi. Pengambilan data dilakukan dengan metode observasi, wawancara, dan dokumentasi. Data didapatkan dari dua sumber, yaitu data primer dan data sekunder. Analisis data dilakukan melalui proses pengumpulan, penyajian data dan penarikan kesimpulan. Penilaian penyelenggaraan Adiwiyata di SDN Model Banyuwangi berdasarkan komponen adiwiyata yang tercantum dalam Peraturan Menteri Lingkungan Hidup nomor 05 tahun 2013. Indikator evaluasi dalam penelitian ini terdiri dari 4 komponen yaitu kebijakan berwawasan lingkungan, pelaksanaan kurikulum berbasis lingkungan, kegiatan lingkungan berbasis partisipatif dan pengelolaan sarana pendukung ramah lingkungan. Hasil penilaian menunjukkan bahwa SDN Model Banyuwangi termasuk dalam kategori sekolah adiwiyata mandiri berdasarkan capaian nilai yang diperoleh dan jumlah binaan sekolah yang telah memenuhi persyaratan namun terdapat hambatan yaitu sarana biopori yang tidak difungsikan secara optimal dan berkurangnya fasilitas ruang kelas sebagai tempat hasil kreasi siswa.
\end{abstract}

Keywords: Program Adiwiyata, Sekolah Peduli Lingkungan, Penilaian

\begin{abstract}
Environmental education is an alternative effort to instill character of environmental care at early age. The type of research is observational study conducted on 20 \& 22 April 2019 at SDN Model Banyuwangi. Data retrieval is done by observation, interviews, and documentation. Data obtained from two sources: primary and secondary data. Data analysis is carried out through process of collecting, presenting data and conclusions. The assessment is based on the adiwiyata component listed in the Minister of Environment Regulation number 05 of 2013. The evaluation indicators in this study consist of 4 components: environmental-oriented policies, implementation of environment-based curriculum, environment-based participatory activities and eco friendly supporting facilities. The results show that SDN Model Banyuwangi included in category of independent high school based on the achievement of the value obtained and the number of schools built that have met the requirement. The obstacle was reduction in classroom facilities as a place for students' creations.
\end{abstract}

Keywords: Adiwiyata Program, Environmental Care-School, Assessment 


\section{PENDAHULUAN}

Seiring dengan meningkatknya permasalahan lingkungan yang terjadi, menjadi hal penting bagi setiap manusia untuk menerapkan gaya hidup cinta lingkungan serta penanaman pendidikan karakter. Dalam upaya pengelolaan lingkungan, karakter yang harus tertanam pada individu adalah karakter peduli lingkungan melalui konsep green school dan green curriculum yang diterapkan pada lembaga di Indonesia salah satunya adalah sekolah (Wardani, 2018). Karakter bukan merupakan bawaan dari masingmasing individu, namun karakter adalah hasil dari proses pendidikan dalam artian luas (Hamzah, 2013). Pendidikan lingkungan hidup merupakan salah satu alternatif upaya yang dilakukan untuk menanamkan karakter peduli lingkungan pada usia dini. Pendidikan lingkungan hidup perlu diberikan pada anak usia sekolah agar mereka memiliki pengetahuan terhadap pengelolaan lingkungan serta dapat menerapkannya dalam kehidupan sehari-hari. Menindaklanjuti terhadap adanya isu lingkungan dan pentingnya penanaman karakter cinta lingkungan sejak usia dini, Kementerian Lingkungan Hidup pada tahun 2006 mencanangkan Program Adiwiyata. Pada tahun 2006, program adiwiyata mulai dilaksanakan khusus di Pulau Jawa, dan diterapkan pada sekolah secara nasional pada tahun 2007 (Kementerian Lingkungan Hidup, 2010). Adiwiyata sendiri merupakan salah satu program dari Kementerian Negara Lingkungan Hidup dalam rangka penerapan kesepakatan bersama antara Menteri Negera Lingkungan Hidup dengan Menteri Pendidikan Nasional Nomor: O3/MENLH/02/2010 dan Nomor: 01/II/KB/2010 (Nurhayati, 2016). Secara umum tujuan penyelenggaraan sekolah adiwiyata adalah untuk mewujudkan masyarakat sekolah yang peduli serta berbudaya lingkungan dengan target sasaran dari program Adiwiyata adalah lingkup pendidikan formal setingkat SD, SMP, SMA atau sederajat (Heny, 2015).

Sekolah yang telah mendapatkan penghargaan Adiwiyata merupakan sekolah yang dianggap berhasil dalam membentuk karakter peduli lingkungan (Al-Anwari, 2014). Sebanding dengan studi yang dilakukan oleh Saragih (2012) yang menunjukkan bahwa program Adiwiyata berpengaruh signifikan terhadap pengetahuan, sikap dan keterampilan lingkungan hidup siswa. Penerapan pendidikan lingkungan hidup pada sekolah peduli dan berbudaya lingkungan efektif dalam menanamkan 
karakter peduli kelestarian sumberdaya alam dan lingkungan (Mulyana, 2009).

Sekolah Dasar Model Banyuwangi merupakan salah satu sekolah dasar di Kabupaten Banyuwangi yang telah menjalankan program adiwiyata sejak tahun 2012. Pada tahun 2016, SDN Model Banyuwangi mampu mencapai predikat sebagai Sekolah Adiwiyata Mandiri. Penghargaan Adiwiyata Mandiri diberikan kepada sekolah yang telah memiliki 10 sekolah binaan yang mendapatkan penghargaan Adiwiyata Kabupaten/Kota, penghargaan diberikan oleh Presiden (Heny, 2015). SDN Model Banyuwangi gencar dalam menanamkan karakter cinta lingkungan pada siswanya. Dengan dimasukkannya kurikulum berbasis lingkungan, penerapan gerakan cinta lingkungan serta penanaman karakter cinta lingkungan oleh guru kepada siswa menjadikan SDN Model Banyuwangi terkenal akan capaian prestasi di bidang lingkungan. Dalam mewujudkan green school, SDN Model Banyuwangi turut berperan serta dalam menjalankan konsep program Adiwiyata. SD Model Banyuwangi meraih berbagai macam penghargaan dalam bidang lingkungan hidup tingkat daerah maupun nasional. Kerja sama dengan lintas sektor dan berbagai pihak telah dilakukan demi mewujudkan lingkungan SDN Model yang hijau dan bersih melalui pelaksanaan program adiwiyata yang berkelanjutan.

Kajian mengenai penyelenggaraan Program Adiwiyata di SDN Model Banyuwangi dilakukan untuk mendeskripsikan implementasi dari komponen sekolah peduli dan berbudaya lingkungan yang telah diterapkan. Berdasarkan observasi yang dilakukan, ditemui pengelolaan tanaman yang masih kurang serta pemilahan sampah yang tidak sesuai dengan jenisnya. Kajian ini menjadi penting dilakukan karena belum ada evaluasi program Adiwiyata yang dilakukan secara menyeluruh oleh pihak sekolah. Penelitian dilakukan dengan mengkaji penyelenggaraan Program Adiwiyata melalui 4 komponen Adiwiyata di SDN Model Banyuwangi serta mengidentifikasi faktor penghambat dalam implementasi program Adiwiyata di SDN Model Banyuwangi.

\section{METODOLOGI}

Jenis penelitian yang digunakan dalam penelitian ini adalah penelitian observasional dengan lokasi penelitian di SDN Model Banyuwangi. Data didapatkan dari dua sumber, yaitu data primer dan data sekunder. Pengambilan data dilakukan dengan metode observasi, wawancara, dan dokumentasi. Observasi dilakukan pada 20 April 2019 dengan 
mengamati sarana-prasarana yang mendukung upaya perlindungan dan pengelolaan Lingkungan Hidup di SDN Model Banyuwangi. Wawancara dilakukan pada 22 April 2019 guna mendukung dan memperkuat hasil observasi di SDN Model. Subjek penelitian ditentukan dengan purposive sampling yaitu informan yang mengetahui program adiwiyata di SDN Model Banyuwangi yakni empat guru. Analisis data dilakukan dengan proses pengumpulan data, penyajian data serta penarikan kesimpulan.

Instrumen disusun berdasarkan Peraturan Menteri Lingkungan Hidup nomor 05 tahun 2013 tentang Pedoman Pelaksanaan Program Adiwiyata, meliputi: 1) Kebijakan Berwawasan Lingkungan; 2) Pelaksanaan Kurikulum Berbasis Lingkungan; 3) Kegiatan Lingkungan Berbasis Partisipatif; dan 4) Pengelolaan Sarana Pendukung Ramah Lingkungan. Dalam komponen kebijakan sekolah berwawasan lingkungan terdapat 2 standar yang dinilai yaitu KTSP memuat Upaya Perlindungan dan Pengelolaan Lingkungan Hidup dan RKAS memuat Upaya Perlindungan dan Pengelolaan Lingkungan Hidup. Pada komponen pelaksanaan kurikulum berbasis lingkungan 2 standar yang dinilai yaitu tenaga pendidik memiliki kompetensi dalam mengembangkan kegiatan pembelajaran lingkungan hidup dan peserta didik melakukan kegiatan pembelajaran tentang perlindungan dan pengelolaan lingkungan hidup. Dalam komponen kegiatan lingkungan berbasis partisipatif 2 standar yang dinilai yaitu melaksanakan kegiatan perlindungan dan pengelolaan lingkungan hidup yang terencana bagi warga sekolah dan menjalin kemitraan dalam rangka perlindungan dan pengelolaan lingkungan hidup dengan berbagai pihak. Pada pengelolaan sarana pendukung ramah lingkungan 2 standar yang dinilai yaitu ketersediaan sarana prasarana pendukung yang ramah lingkungan dan peningkatan kualitas pengelolaan dan pemanfaatan sarana dan prasarana yang ramah lingkungan. Penilaian program adiwiyata dilakukan dengan 4 tahapan. Tahapan 1 yaitu penetapan sebagai sekolah adiwiyata kabupaten/kota jika didapatkan hasil penilaian dengan nilai minimal 56 atau $70 \%$ dari total nilai paling tinggi 80 . Tahapan 2 yaitu sekolah berhak mendapatkan predikat sekolah Adiwiyata tingkat provinsi jika mencapai nilai paling rendah 64 atau $80 \%$ dari total nilai paling tinggi 80. Tahapan 3 yaitu penetapan sekolah adiwiyata nasional apabila mencapai nilai paling rendah 72 atau $90 \%$ dari total nilai paling tinggi 80 . Tahapan 4 
adalah penetapan sekolah Adiwiyata mandiri jika sekolah telah mendapatkan predikat adiwiyata nasional dan

\section{HASIL DAN PEMBAHASAN}

\section{Sekolah Dasar Negeri Model}

Banyuwangi adalah sekolah yang menerapkan implementasi dan penanaman karakter prinsip perlindungan dan pengelolaan lingkungan hidup sejak tahun melakukan pembinaan minimal pada 10 sekolah dengan predikat sekolah adiwiyata kabupaten/kota.

Lingkungan Hidup secara resmi memberikan gelar Adiwiyata Mandiri kepada SDN Model Banyuwangi. Hasil penilaian dari tiap komponen adiwiyata di SDN Model Banyuwangi adalah sebagai berikut;

\section{Pada tahun 2016 Kementrian}

Tabel 1.1 Hasil Penilaian Adiwiyata SDN Model

\begin{tabular}{|c|c|c|c|}
\hline $\begin{array}{l}\text { Kriteria } \\
\text { Penilaian } \\
\text { Adiwiyata }\end{array}$ & Standar & $\begin{array}{l}\text { Nilai } \\
\text { Paling } \\
\text { Tinggi }\end{array}$ & $\begin{array}{c}\text { Nilai } \\
\text { Hasil } \\
\text { Observasi }\end{array}$ \\
\hline \multirow{2}{*}{$\begin{array}{l}\text { Kebijakan } \\
\text { Berwawasan } \\
\text { Lingkungan }\end{array}$} & $\begin{array}{l}\text { Kurikulum Tingkat Satuan Pendidikan } \\
\text { (KTSP) memuat upaya perlindungan } \\
\text { dan pengelolaan lingkungan hidup }\end{array}$ & 10 & 10 \\
\hline & $\begin{array}{llr}\text { Rencana } & \text { Kegiatan dan Anggaran } \\
\text { Sekolah (RKAS) memuat program } \\
\text { dalam upaya perlindungan dan } \\
\text { pengelolaan lingkungan hidup }\end{array}$ & 10 & 10 \\
\hline \multirow{2}{*}{$\begin{array}{l}\text { Pelaksanaan } \\
\text { Kurikulum } \\
\text { Berbasis } \\
\text { Lingkungan }\end{array}$} & $\begin{array}{l}\text { Tenaga pendidik memiliki kompetensi } \\
\text { dalam mengembangkan kegiatan } \\
\text { pembelajaran lingkungan hidup }\end{array}$ & 10 & 8,5 \\
\hline & $\begin{array}{l}\text { Peserta didik melakukan kegiatan } \\
\text { pembelajaran tentang perlindungan dan } \\
\text { pengelolaan lingkungan hidup }\end{array}$ & 10 & 10 \\
\hline \multirow[b]{2}{*}{$\begin{array}{l}\text { Kegiatan } \\
\text { Lingkungan } \\
\text { Berbasis } \\
\text { Partisipatif }\end{array}$} & $\begin{array}{l}\text { Melaksanakan kegiatan perlindungan } \\
\text { dan pengelolaan lingkungan hidup yang } \\
\text { terencana bagi warga sekolah }\end{array}$ & 10 & 9,5 \\
\hline & $\begin{array}{l}\text { Menjalin kemitraan dalam rangka } \\
\text { perlindungan dan pengelolaan } \\
\text { lingkungan hidup dengan berbagai } \\
\text { pihak antara lain: orang tua, alumni, } \\
\text { komite sekolah, LSM, media, dunia } \\
\text { usaha, konsultan, instansi pemerintah } \\
\text { daerah terkait, sekolah lain, dll }\end{array}$ & 10 & 9 \\
\hline \multirow{2}{*}{$\begin{array}{l}\text { Pengelolaan } \\
\text { Sarana } \\
\text { Pendukung } \\
\text { Ramah } \\
\text { Lingkungan }\end{array}$} & $\begin{array}{l}\text { Ketersediaan sarana prasarana } \\
\text { pendukung yang ramah lingkungan }\end{array}$ & 10 & 8 \\
\hline & $\begin{array}{l}\text { Peningkatan kualitas pengelolaan dan } \\
\text { pemanfaatan sarana dan prasarana yang } \\
\text { ramah lingkungan }\end{array}$ & 10 & 8 \\
\hline & JUMLAH & 80 & 73 \\
\hline
\end{tabular}

1) Kebijakan Berwawasan Lingkungan

a. Kurikulum Tingkat Satuan Pendidikan (KTSP) memuat Upaya Perlindungan dan Pengelolaan Lingkungan Hidup.
Penilaian terhadap komponen KTSP memuat upaya perlindungan dan pengelolaan lingkungan hidup menunjukkan nilai yang optimal, 
dengan pencapaian nilai 10 dari nilai paling tinggi 10. Visi, misi, tujuan sekolah yang tertuang dalam Kurikulum Tingkat Satuan Pendidikan di SDN Model Banyuwangi memuat kebijakan perlindungan dan pengelolaan lingkungan hidup. SDN Model memiliki visi yakni "Unggul dalam prestasi, teguh dalam beriman, peduli dan berbudaya lingkungan dan berwawasan global". Adapun misi terkait perlindungan dan pengelolaan lingkungan hidup tercantum pada poin misi ke-5 yaitu "Memberdayakan segenap komponen Sekolah untuk dapat menciptakan budaya sekolah yang sehat, bersih, hijau, asri, indah, aman dan nyaman". Visi misi dan tujuan SDN Model Banyuwangi telah mencerminkan upaya perlindungan dan pengelolaan lingkungan hidup.

Visi, misi dan tujuan SDN Model Banyuwangi terinternalisasi pada warga sekolah. Kepala sekolah, tenaga pendidik yakni guru, komite sekolah, siswa-siswi dan tenaga non-pendidikan tahu dan paham terhadap visi, misi dan tujuan SDN Model Banyuwangi. Hal ini dibuktikan dengan komitmen yang dilakukan kepala sekolah dan warga sekolah dalam mewujudkan misi sekolah dengan melakukan upayaupaya pengelolaan dan perlindungan lingkungan hidup karena SDN Model akan mengikuti penilaian untuk Eco Green ASEAN. Sehingga dalam pencapaiannya SDN Model sudah baik dalam penilaian visi misi dan tujuan.

Menurut Desfandi

(2017) menyebutkan bahwa kebijakan sekolah menjadi landasan bagi lembaga pendidikan dan warganya dalam penyusunan perencanaan dan anggaran serta arah tujuan dari lembaga pendidikan. Kebijakan sekolah berwawasan lingkungan ditujukan untuk menciptakan warga sekolah, yakni peserta didik. Peserta didik diharapkan mampu berepengetahuan, bersikap dan berperilaku ramah lingkungan. Dalam penerapannya, kebijakan sekolah berwawasan lingkungan diharapkan mampu mengubah kebiasaan atau perilaku yang tidak menghargai terhadap sumber daya alam dan lingkungan, menjadi perilaku yang memiliki etika baik dan peduli terhadap sumber daya alam dan lingkungan (Desfandi, 2017).

Dalam upaya menanamkan karakter peduli lingkungan pada siswa, mata pelajaran baik wajib, lokal maupun pengembangan diri di SDN Model Banyuwangi telah diintegrasikan dengan prinsip-prinsip upaya 
perlindungan dan pengelolaan lingkungan hidup.

Kebijakan yang diterapkan di SDN Model Banyuwangi telah mendukung upaya perlindungan dan pengelolaan lingkungan hidup. Sekolah memiliki anggaran dana dan telah dialokasikan secara proporsional untuk mendukung upaya perlindungan dan pengelolaan lingkungan hidup yang didapatkan dari dana BOS (Bantuan Operasional Sekolah).

b. Rencana Kegiatan dan Anggaran Sekolah (RKAS) memuat Program dalam Upaya Perlindungan dan Pengelolaan Lingkungan Hidup

$$
\text { Pada penilaian komponen }
$$

RKAS di SDN Model dinilai telah optimal, yaitu mendapatkan nilai 5 dari nilai paling tingginya adalah 5. Dalam RKAS SDN Model yang disusun telah mencakup peningkatan peran serta masyarakat dan kemitraan serta pengembangan mutu. Selain itu, komponen perencanaan kegiatan lingkungan berbasis partisipatif telah tersusun dalam RKAS SDN Model Banyuwangi.

Dalam pencapaiannya SDN Model memiliki anggaran untuk upaya Pengelolaan dan Perlindungan Lingkungan Hidup yakni sebesar $>20 \%$ dari total anggaran sekolah yakni

berasal dari dana Bantuan Operasional Sekolah (BOS) yang diberikan oleh Kementerian Pendidikan dan Kebudayaan. Salah satu bagian dari kegiatan pembiayaan sekolah adalah tata kelola keuangan. Dalam pengelolaan keuangan secara keseluruhan menuntut kemampuan sekolah untuk dapat merencanakan, mengelola keuangan, mengevaluasi dan mempertanggungjawabkannya secara efektif dan transparan (Mulyasa, 2007). Manajemen keuangan dalam penyelenggaraan pendidikan yang mendukung upaya perlindungan dan pengelolaan lingkungan hidup di SDN Model Banyuwangi merupakan kegiatan yang memiliki pengaruh besar dalam keberlangsungan program adiwiyata di SDN Model Banyuwangi.

2) Pelaksanaan Kurikulum Berbasis Lingkungan

a. Tenaga Pendidik Berpotensi Mengembangkan Kegiatan Pembelajaran Lingkungan Hidup Pada standar tenaga pendidik mendapatkan nilai 9,5 dari total nilai paling tinggi 10. Terdapat 1 komponen yang dinilai kurang optimal yaitu mengikutsertakan peran orang tua siswa dan masyarakat dalam program pembelajaran lingkungan hidup karena presentase keterlibatan orang tua siswa 
dan masyarakat dalam pembelajaran lingkungan hidup tidak memenuhi target.

Dalam pelaksanaan kurikulum berbasis lingkungan diperlukan tenaga pendidik yang terampil dalam mengembangkan pembelajaran yang terintegrasi dengan lingkungan serta sarana dan prasarana yang mendukung dalam pembelajaran terkait lingkungan. Berdasarkan wawancara yang dilakukan, $70 \%$ tenaga pendidik di SDN Model Banyuwangi sudah menerapkan metode yang melibatkan peserta didik secara aktif seperti demonstrasi, diskusi kelompok, pengalaman lapangan, berpendapat, praktek lapangan, penugasan, observasi dan percontohan. Hal ini sesuai dengan pendapat Santroc (1995) bahwa anakanak paling baik belajar melalui pengalaman tangan pertama (langsung) dengan manusia dan benda-benda, dan bermain sangat penting dalam perkembangan total anak karena anak dapat mencoba, menjelajahi, menemukan, menguji coba, merestrukturisasi, berbicara dan mendengar.

Tenaga pendidik juga telah mengembangkan isu lokal dan isu global yang terkait dengan pengelolaan dan perlindungan lingkungan hidup contohnya tenaga pendidik memakai contoh bencana alam yakni dengan bencana longsor yang terjadi di Banyuwangi. Tenaga pendidik yang diwancarai telah mengembangkan indikator pembelajaran, instrumen penilaian serta menyusun rancangan pembelajaran terkait dengan pengelolaan dan perlindungan lingkungan hidup yang terdapat di Kurukulum 2013. Selain itu, dalam mendukung penerapan kurikulum berbasis lingkungan, SDN Model Banyuwangi berupaya untuk mengkomunikasikan hasil-hasil inovasi pembelajaran lingkungan hidup melalui majalah dinding, buletin sekolah, pameran, website, surat kabar, artikel ilmiah dan dalam bentuk karya seni yakni tarian.

SDN Model menggunakan Kurikulum 2013 sebagai kurikulum yang memuat muatan lokal Bahasa Jawa, Bahasa Using dan Pendidikan Lingkungan Hidup serta memuat pengembangan diri yang telah disesuaikan dengan potensi daerah yang merupakan kebijakan dari sekolah. Pelaksanaan kurikulum berbasis lingkungan pada dasarnya merupakan salah satu komponen dalam pelaksanaan program adiwiyata di sekolah. 
b. Peserta Didik yang Menerapkan Pembelajaran Tentang Perlindungan dan Pengelolaan Lingkungan Hidup.

Selain peran serta dari tenaga pendidik, dilakukan penilaian terhadap standar peserta didik. Pada standar peserta didik menerapkan kegiatan pembelajaran perlindungan dan pengelolaan lingkungan hidup mendapatkan nilai 10 dari nilai tertinggi 10. Penilaian pada komponen ini telah optimal.

Siswa SDN Model turut dilibatkan dalam upaya penanaman prinsip perlindungan dan pengelolaan lingkungan hidup. Siswa menghasilkan karya nyata terkait dengan pengelolaan dan perlindungan lingkungan hidup seperti makalah, puisi, lagu, artikel, gambar, seni tari dan produk daur ulang. Hasil karya dari siswa diapresiasi dengan diperlihatkannya karya-karya tersebut di berbagai media, baik media tertulis maupun dipamerkan di mading dan diletakkan pada etalase lorong sekolah. Selain itu, siswa dituntut untuk menerapkan prinsip pengelolaan lingkungan hidup dalam kehidupan sehari-hari di sekolah seperti kewajiban siswa untuk memilah sampah sesuai dengan jenisnya yaitu sampah organik dan anorganik.
3) Kegiatan Lingkungan Berbasis Partisipatif

a. Melaksanakan Kegiatan Perlindungan dan Pengelolaan Lingkungan Hidup Bagi Warga Sekolah

Penilaian pada komponen pemeliharaan dan perawatan gedung dan lingkungan sekolah oleh warga sekolah mendapatkan nilai 8,5 dari nilai tertinggi 10. Sedangkan komponen yang dinilai kurang optimal adalah keterlibatan warga sekolah dalam pemeliharaan gedung dan lingkungan sekolah serta ikutserta warga sekolah pada kegiatan aksi lingkungan hidup yang dilakukan oleh pihak luar.

Perencanaan kegiatan lingkungan berbasis partisipatif dilakukan di SDN Model Banyuwangi dilakukan oleh kepala sekolah yang tercantum dalam Rencana Kegiatan Anggaran Sekolah (RKAS). Komponen upaya perlindungan dan pegelolaan lingkungan hidup yang termuat dalam rencana kegiatan anggaran sekolah diantaranya adalah kurikulum dan kegiatan pembelajaran lingkungan hidup, pengadaan sarana dan prasarana pendukung pengelolaan lingkungan hidup, pengembangan mutu serta peningkatan peran masyarakat dan mitra lain dalam upaya kegiatan pengeloaan lingkungan hidup. Warga 
SDN Model Banyuwangi terlibat dalam pemeliharaan gedung dan lingkungan sekolah, yang diwujudkan dengan pelaksanaan berbagai kegiatan dan program diantaranya: piket kebersihan kelas, jum'at bersih, lomba kebersihan kelas dan kegiatan pemeliharaan taman oleh masing-masing kelas. Warga sekolah memanfaatkan lahan dan fasilitas sekolah sesuai kaidah-kaidah perlindungan dan pengelolaan lingkungan hidup antara lain; pemeliharaan tanaman obat keluarga, hutan sekolah, pembibitan, kolam dan pengelolaan sampah. Namun dalam hal ini, pemeliharaan terhadap tanaman hias di depan kelas masih kurang optimal. SDN Model Banyuwangi memiliki hutan yang disebut dengan hutan Agung Wilis yang berfungsi sebagai hutan sekolah. Selain itu, terdapat taman yang ditanami tanaman obat keluarga yang pemeliharaannya turut melibatkan peran serta siswa sekolah. Pembibitan dilakukan di green house. Sedangkan pengelolaan sampah SD Model sudah terbagi menjadi 2, yaitu sampah organik dan anorganik. Untuk sampah anorganik yang layak pakai dapat dikreasikan menjadi berbagai ketrampilan yang indah dan fungsional. Pengelolaan sampah organik dilakukan dengan mengolah sampah organik menjadi kompos siap pakai dan bahkan siap jual untuk diedarkan ke luar kota. Namun, berdasarkan observasi yang dilakukan terlihat di beberapa tempat sampah, sampah yang terbuang masih belum terpilah dengan baik.

Kegiatan

pengembangan softskill siswa melalui kegiatan ekstrakulikuler telah mendukung upaya perlindungan dan pengelolaan lingkungan hidup. Kegiatan ekstrakulikuler seperti karya ilmiah remaja, pramuka, palang merah remaja, dan dokter kecil dimanfaatkan untuk pembelajaran terkait dengan perlindungan dan pengelolaan lingkungan hidup. Dalam pelaksanaan berbagai ekstra kurikuler di SDN Model Banyuwangi telah memuat pembelajaran mengenai pengomposan, tanaman obat keluarga, biopori, daur ulang dan pertanian organik. Muatanmuatan ini ditanamkan diantaranya melalui kegiatan ekstrakulikuler yang ada. Di SDN Model Banyuwangi terdapat 8 titik biopori yang berfungsi sebagai media pembelajaran bagi siswa sekolah.

Pengembangan kreativitas dan inovasi warga sekolah dalam upaya perlindungan dan pengelolaan lingkungan hidup terlihat pada adanya 
kegiatan daur ulang sampah, pemanfaatan dan pengolahan air, karya ilmiah, karya seni dan hemat energi. Kegiatan daur ulang sampah telah dilakukan guna mengurangi produksi sampah anorganik di SDN Model Banyuwangi. Sampah anorganik layak pakai dirubah fungsinya menjadi berbagai ketrampilan melalui pemberdayaan siswa sekolah. Pengolahan air dilakukan pada sistem limbah sisa air wudhu yang disalurkan menuju bak penampung. Sehingga air yang telah diolah dalam sistem ini dapat digunakan sebagai air untuk menyiram tanaman.

Berbagai mata pelajaran di SD Model Banyuwangi memberikan pembelajaran bagi siswa-siswanya untuk terlatih dalam menyusun karya ilmiah di bidang perlindungan dan pengelolaan lingkungan hidup. Dalam upaya penghematan energi, SDN Model Banyuwangi gencar menanamkan kebiasaan ini pada siswa didik. Hal ini dapat dilihat dari posterposter yang memuat tentang himbauan untuk menghemat energi dan menggunakan energi dengan seperlunya yang ditemukan di berbagai titik sekolah.

Dalam waktu dekat, SDN Model Banyuwangi akan membangun dan menerapkan sistem panel surya sebagai sumber energi alternatif. Sumber energi alternatif merupakan salah satu klasifikasi kegiatan dalam aspek ini yang belum dicapai oleh SDN Model Banyuwangi. Adanya sistem panel surya ini merupakan salah satu bentuk upaya pelengkapan sarana dan prasarana pendukung pengelolaan lingkungan hidup. Sistem panel surya merupakan sumber energi listrik alternatif dengan memanfaatkan perubahan energi sinar matahari menjadi energi listrik dengan proses efek fotovaltic. Pemanfaatan panel surya sebagai sumber energi alternatif untuk mensuplai kebutuhan listrik lebih efisien jika dibandingkan dengan penggunaan genset sebagai sumber dayanya (Purwoto, 2018). Penggunaan sistem panel surya dalam pelaksanaan sekolah adiwiyata di SDN Model Banyuwangi dapat mengurangi kebutuhan listrik yang bersumber dari PLN dengan biaya investasi dan biaya operasional panel surya yang lebih murah.

Selain itu, SDN Model mengikuti kegiatan aksi lingkungan hidup yang dilakukan oleh pihak luar dengan turut berpartisipasi mengikuti kegiatan yang diselenggarakan oleh pemerintah daerah Banyuwangi, dinas 
lingkungan hidup, dinas kesehatan pangan serta instansi lainnya. Penilaian implementasi dari standar ini menunjukkan bahwa SDN Model Banyuwangi belum mencapai nilai tertinggi karena belum memenuhi target jumlah kegiatan aksi yang ditetapkan. Keterlibatan warga sekolah dalam pemeliharaan gedung dan lingkungan sekolah juga dinilai belum optimal karena perawatan terhadap salah satu komponen lingkungan sekolah yaitu tanaman hias masih kurang. Terlihat dari beberapa tanaman hias yang diletakkan di depan kelas dalam keadaan kering, layu dan tidak terawat.

b. Menjalin Kemitraan dengan Berbagai Pihak dalam Rangka Perlindungan dan Pengelolaan Lingkungan Hidup

Dalam komponen menjalin kemitraan dengan berbagai pihak mendapatkan nilai 9 dari nilai tertinggi yaitu 10. Komponen yang belum mendapatkan nilai optimal adalah memanfaatkan narasumber dalam meningkatkan pembelajaran lingkungan hidup karena terbatasnya jumlah narasumber yang diundang.

SDN Model Banyuwangi telah menjalin kemitraan dalam rangka perlindungan dan pengelolaan lingkungan hidup dengan berbagai pihak antara lain: orang tua, alumni, komite sekolah, LSM, media, dunia usaha, konsultan, instansi pemerintah daerah terkait dan sekolah lain. Dalam pencapaiannya SDN Model Banyuwangi memanfaatkan dua narasumber yaitu Dinas Lingkungan Hidup dengan memberikan pembelajaran terkait pengolahan sampah dan pengomposan dan Dinas Kesehatan Pangan.

SDN Model Banyuwangi didukung oleh lebih dari tiga mitra dalam bentuk materi untuk kegiatan pengelolaan lingkungan hidup. Mitra tersebut diantaranya adalah penerbit buku Yudhistira yang memberikan tong sampah untuk pengomposan, lembaga bimbingan belajar neutron yang memberikan banner yang mempromosikan aksi cinta lingkungan hidup.

Kegiatan pengelolaan lingkungan hidup juga didukung oleh komunitas mobil hijau dan Dinas Lingkungan Hidup. Selain itu, SDN Model turut melibatkan peran serta komite sekolah yang terdiri dari wali murid siswa. Bantuan untuk kantin sehat berupa meja payung diberikan oleh BNI 46 Cabang Banyuwangi dalam rangka peningkatan mutu kantin sehat di SDN Model Banyuwangi. 
Diantara peran komite sekolah adalah memberikan anggaran dana untuk mendukung pembelajaran lingkungan hidup dan upaya perlindungan dan pengelolaan lingkungan hidup. Pelibatan warga sekolah SDN Model Banyuwangi dalam kegiatan pengelolaan lingkungan hidup bertujuan untuk menanamkan kesadaran dan kepedulian terhadap lingkungan sekitar.

Kegiatan pengelolaan lingkungan di SDN Model Banyuwangi dilakukan oleh siswa, guru dan jajarannya, petugas kebersihan dan komite sekolah.

4) Pengelolaan Sarana Pendukung Ramah Lingkungan

a. Ketersediaan Sarana Prasarana Pendukung yang Ramah Lingkungan.

Pada komponen ini mendapatkan nilai 8 dari total nilai tertinggi 10 . Komponen yang dinilai belum optimal adalah penyediaan sarana dan prasarana untuk mengatasi permasalahan lingkungan hidup di sekolah.

Penerapan kurikulum berbasis lingkungan yang didukung dengan ketersediaan sarana prasarana pendukung program Adiwiyata yang lengkap dan memadai tidak dapat berjalan secara berkelanjutan tanpa adanya pengelolaan terhadap sarana yang ada. Menurut Tatang Amirin, dkk. (2010), pengelolaan sering diartikan sama dengan manajemen, yaitu suatu ilmu dan seni yang didalamnya terdapat kegiatan perencanaan, pengorganisasian, dan pengontrolan untuk mencapai tujuan secara efektif dan efesien. Sedangkan Rohiat (2006) berpendapat bahwa manajemen sarana dan prasarana adalah kegiatan mengatur untuk mempersiapkan segala peralatan material bagi terselenggaranya proses pendidikan di sekolah. Tujuan dari adanya pengelolaan sarana prasarana sekolah adalah untuk menciptakan fasilitas belajar yang memadai sehingga siswa dapat belajar dengan optimal.

Sarana biopori yang ada di SDN Model Banyuwangi belum dapat dimanfaatkan secara optimal. Biopori hanya digunakan sebagai alat pembelajaran bagi siswa dan tidak difungsikan untuk menyerap air hujan sebagaimana fungsi biopori pada umumnya.

b. Peningkatan Kualitas Pengelolaan dan Pemanfaatan Sarana Prasarana Ramah Lingkungan

Pada komponen peningkatan kualitas pengelolaan dan pemanfaatan 
sarana prasarana ramah lingkungan mendapatkan nilai 10 dari total nilai tertinggi yaitu 10. Keseluruhan komponen pada penilaian ini dinilai telah optimal.

Pengelolaan sarana prasarana penting dilakukan untuk menjamin dan melindungi properti dan peralatan yang ada dari bahaya kerusakan serta limbah melalui adanya pemeliharaan yang baik dan benar. Program Adiwiyata yang dilaksanakan di SDN Model Banyuwangi secara keseluruhan sudah baik, termasuk dalam hal ini adalah upaya pengelolaan sarana dan prasarana pendukung ramah lingkungan. ketersediaan sarana dan prasarana di SDN Model Banyuwangi sudah cukup lengkap, terlihat dengan adanya kelengkapan sarana kebersihan seperti tersedianya tempat sampah yang terpisah, komposter, pengolahan air limbah/drainase, ruang terbuka hijau, pemanfaatan dan pengolahan air, adanya hutan/taman/kebun sekolah, adanya green house, tanaman obat keluarga, kolam ikan, biopori dan adanya kantin sehat. Selain itu, dalam rangka perlindungan dan pengelolaan lingkungan hidup komite turut berperan dalam memelihara sarana dan prasarana sekolah ramah lingkungan. Bentuk keterlibatan komite ditunjukkan dengan memberikan upah untuk petugas kebersihan. Namun perawatan terhadap tanaman hias yang berada di luar kelas dan di lorong sekolah kurang begitu diperhatikan. Hal ini menyebabkan berkurangnya tingkat estetika dari lingkungan yang ada di sekitarnya.

Secara keseluruhan, hasil penilaian terhadap komponen adiwiyata di SDN Model Banyuwangi adalah 73 dari total nilai paling tinggi 80 dengan memiliki sekolah lebih dari 10 sekolah binaan. Nilai ini telah memenuhi kriteria adiwiyata mandiri. Hasil penilaian adiwiyata di SDN Model Banyuwangi telah sesuai dengan predikat adiwiyata mandiri yang sekarang dimiliki oleh SDN Model Banyuwangi.

Dalam pelaksanaan program Adiwiyata di SDN Model Banyuwangi ditemukan beberapa hambatan yang menyebabkan pelaksanaan program Adiwiyata menjadi kurang maksimal. Diantara hambatan ditemui dalam penyelenggaraan Adiwiyata di SDN Model Banyuwangi adalah sarana biopori yang tidak dapat difungsikan secara optimal. Di SDN Model Banyuwangi terdapat 8 titik biopori yang berfungsi sebagai media pembelajaran bagi siswa sekolah. Sarana biopori di SDN Model Banyuwangi hanya berfungsi sebagai 
pembelajaran saja, tidak difungsikan untuk menyerap air sebagaimana mestinya. Hal ini dikarenakan kondisi SDN Model Banyuwangi yang tanahnya memiliki tekstur seperti tanah rawa, sehingga tidak memungkinkan untuk penerapan biopori. Selain itu, berkurangnya fasilitas ruangan kelas turut menjadi hambatan. Sejak tahun 2017, lahan bagian belakang SDN Model Banyuwangi telah dimanfaatkan oleh Universitas Airlangga sebagai tempat untuk kegiatan perkuliahan. Hal ini berdampak pada pengurangan ruangan yang dulunya berfungsi sebagai tempat meletakkan kreasi siswa dari sampah anorganik menjadi tidak ada. Sehingga hasil kreasi siswa ditempatkan secara menumpuk di salah satu ruangan yang sempit.

\section{KESIMPULAN}

Sekolah Dasar Negeri Model merupakan sekolah dasar yang sudah ditetapkan menjadi Sekolah Adiwiyata Mandiri pada tahun 2016 oleh Kementrian Lingkungan Hidup. Hasil penilaian terhadap 4 komponen adiwiyata di SDN Model Banyuwangi menunjukkan bahwa SDN Model Banyuwangi termasuk dalam kategori sekolah adiwiyata mandiri berdasarkan capaian nilai yang diperoleh dan jumlah binaan sekolah yang telah memenuhi persyaratan. Terdapat beberapa penilaian yang kurang optimal yaitu pada komponen partisipasi warga sekolah dalam kegiatan aksi lingkungan hidup yang diadakan oleh pihak luar, penyediaan sarana prasarana pendukung yang ramah lingkungan serta keterlibatan wali murid dalam program pembelajaran lingkungan hidup. Hambatan dalam penyelenggaraan program Adiwiyata di SDN Model Banyuwangi adalah sarana biopori yang tidak dapat difungsikan secara optimal serta berkurangnya fasilitas ruangan kelas yang ada dapat dimanfaatkan sebagai tempat hasil kreasi siswa. Rekomendasi yang diberikan adalah SDN Model lebih meningkatkan pengelolaan terhadap sarana prasarana pendukung program pembelajaran lingkungan hidup serta meningkatkan keterlibatan aktif dalam kegiatan aksi lingkungan yang diadakan oleh pihak luar sehingga penanaman karakter peduli lingkungan pada siswa menjadi lebih optimal. Kedepannya diharapkan SDN Model tidak hanya fokus pada pembaruan terhadap sarana prasarana saja, namun dapat lebih ditingkatkan pengelolaan sarana pendukung ramah lingkungan khususnya perawatan terhadap tanaman di SDN Model Banyuwangi. Hasil kreasi siswa dapat dipilah dan diletakkan di masing-masing kelas maupun di lorong sekolah sehingga 
permasalahan terkait berkurangnya fasilitas ruang sebagai tempat hasil karya dapat teratasi.

\section{DAFTAR PUSTAKA}

Amirin, M. Tatang et al. (2010). Manajemen Pendidikan:

Yogyakarta. UNY Pres

Al-Anwari, A.M., 2014. Strategi

Pembentukan Karakter Peduli

Lingkungan di Sekolah Adiwiyata Mandiri 26.

Arikunto, 2006. Metode Penelitian Kualitatif. Jkt. Bumi Aksara.

Desfandi, Mirza., dkk. 2017. Implementasi Kebijakan Sekolah Berwawasan Lingkungan sebagai Upaya Mengembangkan Literasi Ekologis Peserta Didik. Sosio Didaktika : Social Sciense

Education Journal, Vol.4 No.2

Hamzah, S., 2013. Pendidikan

Lingkungan: Sekelumit Wawasan Pengantar. Bdg. Refika Aditama.

Heny Puspita, 2015. Adiwiyata Mewujudkan Sekolah yang Berbudaya Lingkungan.

Kementerian Lingkungan Hidup,

Kementerian Pendidikan dan Kebudayaan. 2010.. Panduan Adiwiyata "Sekolah Peduli dan Berbudaya Lingkungan". Jakarta
Mahmudah, Kholifatul., dkk. Partisipasi Masyarakat Dalam Program Sekolah Adiwiyata Mandiri (Studi Multisitus Di SDN Pandanwangi 1 Malang dan SDN Purwantoro 1 Malang). Universitas Negeri Malang. Online: . Diakses pada: $17 / 05 / 2019$

Mulyana, R., 2009. Penanaman Etika Lingkungan melalui Sekolah Perduli dan Berbudaya Lingkungan 6.

Nur, Aisyah, and Risma Niswaty. "Efektivitas Pelaksanaan Program Sekolah Adiwiyata di SDN Mangkura 1 Makassar," n.d., 5. Baru. Jkt. UIP.

Nurhayati, Ela. 2016. Implementasi Kurikulum Berbasis Lingkungan di Sekolah Adiwiyata (Studi Kasus di SMP Negeri 16 Surabaya). Universitas Negeri Surabaya : Fakultas Ilmu Psikologi

Rahmah, Yanti Dwi, and Sjamsiar Sjamsuddin Indradi. "Implementasi Program Sekolah Adiwiyata (Studi pada SDN Manukan Kulon III/540 Kota Surabaya)," n.d., 5.

Rohiat. 2006. Manajemen Sekolah: Teori Dasar dan Praktik. Bandung: Refika Aditama. 
Saragih, A. 2012. Pengaruh Program Adiwiyata terhadap Kognitif Afektif dan Psikomotorik Lingkungan Hidup Siswa Sekolah Dasar di Kota Medan. Medan: Universitas Sumatera Utara.

Peraturan Menteri Lingkungan Hidup Nomor 5 tahun 2013 tentang Pedoman Pelaksanaan Program Adiwiyata

Purwoto, Bambang Hari., dkk. 2018. Efisiensi Penggunaan Panel Surya Sebagai Sumber Energi Alternatif. Jurnal Emitor Vol.18 No. 01. Fakultas Teknik, Universitas Muhammadiyah Surakarta.

Rotari, Septi. "Peran Program Adiwiyata Mandiri dalam Meningkatkan Kepedulian Lingkungan Peserta Didik." Citizenship Jurnal Pancasila dan Kewarganegaraan 5, no. 1 (April 29, 2017): 42. https://doi.org/10.25273/citizenshi p.v5i1.1177.

Sugiyantono, Indri. 2015. Pengelolaan

Kegiatan Lingkungan Berbasis Partisipatif Sekolah Adiwiyata di SMPN 6 Salatiga. Universitas Muhammadiyah Surakarta. Online:

. Diakses pada: 17/05/2019

Wardani, D.N.K., 2018. Implementasi Program Adiwiyata dalam Membina Karakter Peduli
Lingkungan Bagi Siswa (Studi Kasus di MIN 1 Ponorogo). IAIN Ponorogo. 